\section{Scale for Esports Spectator \\ Demands: Adaptation to Turkish, validity and reliability study}

\section{Espor İzleyici Talepleri Ölçeği: Türkçe'ye uyarlama, geçerlik ve güvenirlik çalışması}

\author{
Alp Kaan Kilci ${ }^{1}$ \\ Serhat Yalçıner ${ }^{2}$
}

\section{Abstract}

The purpose of this study was to adapt to Turkish and to determine the validity and reliability of the Scale for Esports Spectator Demand (SESD), which was developed to determine the demands of the viewers who follow the esports broadcasts by Qian, Zhang, Wang and Hulland (2020). After the Turkish form equivalence test, the scale was applied to viewers who following esports broadcasts on the online broadcast network "Twitch". A total of 495 volunteers $(21.43 \pm 3.50), 423$ men (21.71 \pm 3.51$)$, and 72 women (19.75 \pm 2.95$)$, aged between 18-32, participated in the online study. Exploratory (EFA) and confirmatory factor analysis (CFA) was performed on the data obtained. A total of 7 factors were determined with EFA, respectively, 4 overlapping items (21-11-18-29), 2 items that make up a single factor (19-20) and the 30th item that disrupted the meaning integrity of the factor to which it belongs were removed from the scale. It was seen that the model consisting of the remaining 25 items and 6 dimensions explained $67.278 \%$ variance and the 6 -factor model had an acceptable fit as a result of CFA. $\left(\chi^{2} / \mathrm{df}=2,622 ; \quad\right.$ GFI $=, 896 ; \quad$ AGFI $=, 892 ;$ $\mathrm{CFI}=, 918 ; \quad \mathrm{NFI}=, 902 ; \quad \mathrm{RMR}=, 064 ;$

\section{Özet}

Bu çalışma'nın amacı, Qian, Zhang, Wang ve Hulland (2020) tarafindan espor yayınlarını takip eden izleyicilerin yayından taleplerini belirlemek amacıyla geliştirilmiş olan Scale for Esports Spectator Demand (SESD)'in Türkçe'ye uyarlanması, geçerlik ve güvenirliği'nin belirlenmesidir. Ölçek, Türkçe form eş-değerlik sınamasının ardından Türkiye genelinde çevrimiçi yayın ağ1 "Twitch" üzerinden espor yayınlarını takip eden izleyicilere uygulanmıştır. Çevrimiçi ortamda gerçekleştirilen çalışmaya yaşları 18-32 arasında değişen 423 erkek $(21,71 \pm 3,51)$ ve 72 kadin $(19,75 \pm 2,95)$ olmak üzere toplam 495 gönüllü birey $(21,43 \pm 3,50$ katılmıştır. Elde edilen veriler üzerinde açımlayıcı (AFA) ve doğrulayıcı faktör analizi (DFA) gerçekleştirilmiştir. AFA ile toplam 7 faktör belirlenmiş, sırasıyla binişik olan 4 madde (21-11-18-29), tek bir faktörü oluşturan 2 madde (19-20) ve ait olduğu faktördeki anlam bütünlüğünü bozan 30. madde ölçekten çıkarılmıştır. Kalan 25 madde ve 6 boyuttan oluşan modelin \%67,278 varyansı açıkladığ1 ve DFA sonucunda 6 faktörlü modelin kabul edilebilir bir uyuma sahip olduğu görülmüştür $\left(\chi^{2} / \mathrm{df}=2,622 ; \quad \mathrm{GFI}=, 896 ; \quad \mathrm{AGFI}=, 892 ;\right.$ $\mathrm{CFI}=, 918 ; \quad \mathrm{NFI}=, 902 ; \quad \mathrm{RMR}=, 064 ;$

\footnotetext{
1 Arş. Gör., Balıkesir Üniversitesi, Spor

iD Orcid ID: 0000-0001-6445-6400

2 Arş. Gör., Balıkesir Üniversitesi, Spor Bilimleri Fakültesi, serhat.yalciner@balikesir.edu.tr iD Orcid ID: 0000-0002-9888-4777
} 
Kilci, A. K., \& Yalçıner, S. (2020). Espor İzleyici Talepleri Ölçeği: Türkçe’ye uyarlama, geçerlik ve güvenirlik çalışması. Journal of Human Sciences, 17(4), 1106-1122. doi:10.14687/ihs.v17i4.6087

RMSEA=,071). It was determined that the internal consistency coefficients of the scale on the basis of sub-dimensions ranged between .755 and .863 , and the overall internal consistency coefficient was $\alpha=.924$ As a result, it was determined that the Scale for Esports Spectator Demand (SESD), adapted to Turkish, can be used as a valid and reliable measurement tool to determine the demands of esports spectator.

Keywords: Esports, spectator, demand, scale, adaptation, validity, reliability.

(Extended English summary is at the end of this document)
RMSEA=,071). Ölçeğin alt boyutlar bazında iç tutarlilık katsayılarının ,755 ile ,863 arasında değiştĭgi, genel iç tutarlılık katsayısının ise $\alpha=$ ,924 olduğu tespit edilmiştir. Sonuç olarak, Türkçe'ye uyarlama çalışması yapılmış olan Espor İzleyici Talepleri Ölçeği (ESİTÖ)'nün espor izleyicilerinin taleplerini belirlemek için geçerli ve güvenilir bir ölçüm aracı olarak kullanılabileceği belirlenmiştir.

Anahtar Kelimeler: Espor, izleyici, talep, ölçek, uyarlama, geçerlik, güvenirlik.

\section{Giriş}

Yayın ağlarının (internet, televizyon vb.) küreselleşmesiyle birlikte yayınlar, aynı anda yüzbinlerce hatta milyonlarca izleyiciye erişim sağlayabilme potansiyeline ulaşmıştır. Bununla birlikte küresel çapta yayınlanan ve izlenen, son zamanlarda popülerliğini artıran etkinliklerden bir tanesi de "Espor"dur. Espor; çeşitli ligleri bulunan, turnuvaları düzenlenen ve genellikle çeşitli sponsorlar ile desteklenen profesyonel/amatör takımlar arasında gerçekleştirilen rekabetçi video oyun faaliyetleridir (Hamari ve Sjöblom, 2017). Esporlar, video oyunlarının ve profesyonel sporların bir kesişim noktası olarak görülebilir (Brown, Billings, Murphy ve Puesan, 2018). Bilim insanları, önceki araştırmalarda geleneksel sporlar ve esporlar arasında tutarlı bir uyum olduğunu ortaya koymuş, espor olgusunu araştırmak için bu uyumdan yararlanmışlardır (Funk, Pizzo ve Baker, 2018; Heere, 2018; Cunningham ve ark., 2018; Hallmann ve Giel, 2018). Yine de espor türlerinin karmaşıklı̆̆ ve yayın platformlarının kültürü göz önüne alındığında; geleneksel sporlarla bağlantılı olmayan ancak esporlarda mevcut olan farklı özellikler ve işlevler olabileceğini öne sürmüşlerdir (Brown ve ark., 2018; Pizzo, Baker, Na, Lee, Kim ve Fung, 2018; Hamari ve Sjöblom, 2017; Lee ve Schoenstedt, 2011; Lee, An ve Lee, 2014). Hizla büyüyen espor endüstrisi, ulusal ve uluslararası espor kuruluşlarının (Uluslararası Espor Federasyonu, Türkiye Espor Federasyonu, vb.) oluşmasıyla birlikte organize bir yapıya sahip olmuştur (Seo, 2013). Espor ve geleneksel sporlar (futbol, basketbol vb.); profesyonel oyuncuların, takımların ve antrenörlerin olması, ligler ve turnuvalar şeklinde gerçekleştirilmesi ve oyuncu transfer ücretlerinin bulunması gibi benzer özelliklere sahiptir (Pizzo ve ark., 2018). Espor etkinlikleri, genellikle espor turnuva organizasyonları (örn; ESL) ve bireysel olarak profesyonel/amatör oyuncular tarafindan (Taylor, 2016) yayın platformları (Twitch, Youtube vb.) aracılığıyla izleyicilerin erişimine sunulmaktadır. Bunlarla birlikte, son zamanlarda televizyon kanallarının da espor müsabakalarını yayınlamaya başladığı görülmektedir. Bunun espor etkinliklerinin sürekli büyüyen bir izleyici kitlesine sahip olmasindan (Statista, 2020) ve reklam/sponsorluk gelirlerinin her geçen yll artmasindan (Newzoo, 2020) kaynaklandığı düşünülmektedir.

Dünya çapında espor izleyicilerinin toplam sayısı 2018'den 2019'a, bir yılda 395 milyon izleyiciden 443 milyon izleyiciye ulaşarak yaklaşı $\% 12$ oranında bir artış göstermiştir. İzleyici sayısındaki bu artışın devam etmesi ve 2020 sonunda 495 milyona; 2023 sonunda ise 646 milyona ulaşması beklenmektedir (Statista, 2020). Bununla birlikte son zamanlarda en çok izlenen etkinliklerden birisine örnek olarak, aynı anda 200 milyondan fazla izleyici tarafindan takip edilmiş olan 2018 LoL Dünya Şampiyonası (Worlds 2018) gösterilebilir (Charts, 2018). Küresel espor gelirlerine bakıldığında ise 2019'da, 2018'e göre yaklaşık \%26 artışla birlikte yaklaşık 1.1 milyar 
Kilci, A. K., \& Yalçıner, S. (2020). Espor İzleyici Talepleri Ölçeği: Türkçe’ye uyarlama, geçerlik ve güvenirlik çalışması. Journal of Human Sciences, 17(4), 1106-1122. doi:10.14687/ihs.v17i4.6087

dolara yükseldiği görülmekte iken; 2020 sonunda yaklaşık 1.34 milyar dolara, 2022'de ise yaklaşık 1,79 milyar dolara yükselmesi beklenmektedir (Newzoo, 2019; Newzoo, 2020). Espor ekonomisi ve izleyici kitlesi büyümesini istikrarlı olarak devam ettirmektedir. Bunun sonucu olarak, espor konusunda bilimsel araştırmaların artırılması ve izleyicilerin sahip olduğu çeşitli özelliklerin incelenmesi gerektiği düşünülmektedir. Bunlardan bir tanesi espor izleyicilerinin yayından/yayıncıdan talepleridir.

Türk Dil Kurumu Sözlüğ̈̈’ne (2020) göre talep: "Yerine getirilmesi başkasından istenilen şey, meram, istek" ş̧eklinde ifade edilmiştir. Ekenci ve İmamoğlu (2002), sportif hizmet ve programlara "talep" olgusunun "Yeterli satın alma gücü ve boş zamana sahip olan; belirli zaman diliminde, belirli hedefler doğrultusunda sportif hizmet ve programlardan yararlanmak isteyen kişi ya da gruplar." şeklinde ele alınabileceğini belirtmişlerdir. Ayrıca bu hizmetleri talep eden kitlenin spora direkt olarak katılım gösterenlerden oluşabileceği gibi seyircilerden de oluşabileceğini belirterek; spor işletmesinin ürettiği spor programlarını tüketen müşterinin, işletmenin varlığının sürdürülebilmesi açısından çok önemli bir faktör olduğunun da altını çizmişlerdir. Bununla birlikte ortaya koyulan hizmetin kalitesinin "beklentilere uygunluk" kavramı ile açılanabileceği ve hizmetin niteliğinin değerlendirmesinin müşteri memnuniyeti ile takip edilebileceği belirtilmiştir (Ekenci ve İmamoğlu, 2002). Bu bilgiler doğrultusunda, espor yayınlarını takip eden izleyicilerin satın alma gücü olmaksızın bu spor programlarına izleyici olarak katılabildiği ve bu kaynakların birer tüketicisi olduğu yadsınamaz bir gerçektir. Bu doğrultuda izleyici talepleri; izleyicinin yayınlarda/yayıncılarda olmasını istedikleri ve istemedikleri nitelikler olarak açıklanabilir. Yayıncıların beklentilerden kaynaklanan bu taleplerden haberdar olmasının; dolayısıyla bu talepleri karşılamak için girişimlerde bulunmasının, daha fazla izleyiciye ulaşmak ve mevcut izleyici kitlesini memnun etmek açısından önemli olduğu düşünülmektedir. Buna birkaç örnek verecek olursak; bireysel olarak yayın yapan ve yayın esnasinda yorumları okuyup cevap vermede eksik kalan bir yayıncinın, yorumlarına cevap alma beklentisinde bulunan izleyicileri kaybetme olasıllğı da artacaktır. Benzer şekilde; yüksek görüntü akıcıllğı ve kalitesine sahip olmayan bir yayın gerçekleştiren yayıncının, yüksek görüntü akıcılığı ve kalitesi beklentisinde olan izleyicileri kaybetme olasıllğ̆1 da artacaktır. Yayıncıların, bunlara benzer birçok boyuta sahip olan izleyici beklentilerini belirleyerek, yayınlarını bu beklentiler doğrultusunda şekillendirmeleri, daha büyük kitlelere ulaşmalarına ve izleyicilerinin daha büyük kısmını memnun etmelerine aracılık edeceği düşünülmektedir.

İzleyici taleplerinin belirlenmesinin ve dikkate alınmasının; yayın, yayıncı kalitesi ve izleyici memnuniyetinin artırılmasında önemli bir yer tuttuğu düşünülmektedir. Dünya genelinde ve ülkemizde espor üzerine yapılan akademik çalışmaların sayısının arttı̆̆ı görülmektedir. Fakat büyük bir izleyici kitlesine sahip espor alanında, izleyicilerin taleplerini belirlemek için kullanılabilecek Türkçe ölçme aracı (envanter, ölçek vb.) bulunmamaktadır. Bu nedenle izleyici taleplerinin belirlenmesi ve bu amaç doğrultusunda ölçme araçlarının geliştirilmesi veya Türkçe'ye kazandırılması gerektiği düşünülmektedir. Bu doğrultuda, gerçekleştirilen bu araştırmanın amacı Qian, Zhang, Wang ve Hulland (2020) tarafindan geliştirilen Scale for Esports Spectator Demands (SESD)'in Türkçe uyarlamasının yapılması, geçerlik ve güvenirlik çalışmasının gerçekleştilmesidir.

\section{Yöntem}

\subsection{Araştırma Grubu}

Bu çalışmanın evrenini Türkiye'de Twitch yayın platformu üzerinden; CS:GO, PUBG, DotA 2, LoL, Valorant ve WoW yayınlarını takip eden izleyiciler oluşturmuştur. Belirlenen izleyici grubunun tamamına ulaşma olanağı bulunmadığından dolayı evren içerisinden örneklemin belirlenmesine ihtiyaç duyulmuştur. Araştırma verileri toplanırken amaçlı örnekleme tekniği kullanılmıştır. Tabachnick ve Fidell (2007) örneklem büyüklüğünün, toplam ifade sayısının 8 katına 50 eklenerek hesaplanabileceğini; Sekaran (2003) ise yüzbinden büyük evrenler için 384 kişilik örneklem büyüklügünün yeterli olacağını belirtmiştir. Bu doğrultuda mevcut çalışmanın örneklem büyüklüğü (495) literatürde belirtilen örneklem büyüklüğ̈nü karşılamaktadır. 
Kilci, A. K., \& Yalçıner, S. (2020). Espor İzleyici Talepleri Ölçeği: Türkçe’ye uyarlama, geçerlik ve güvenirlik çalışması. Journal of Human Sciences, 17(4), 1106-1122. doi:10.14687/jhs.v17i4.6087

Tablo 1. Katılımcıların Demografik Özellikleri

\begin{tabular}{|c|c|c|c|c|c|c|c|}
\hline \multicolumn{2}{|c|}{ Demografik Özellikler } & \multirow{2}{*}{$\frac{\mathbf{N}}{423}$} & \multirow{2}{*}{$\begin{array}{c}\% \\
85,5\end{array}$} & \multicolumn{2}{|c|}{ Demografik Özellikler } & \multirow{2}{*}{$\frac{\mathbf{N}}{306}$} & \multirow{2}{*}{$\begin{array}{c}\mathbf{\%} \\
61,8\end{array}$} \\
\hline \multirow{2}{*}{ Cinsiyet } & Erkek & & & \multirow{3}{*}{ Yaş } & $\begin{array}{l}18-22 \\
\text { aras1 }\end{array}$ & & \\
\hline & Kadın & 72 & 14,5 & & $\begin{array}{l}23-27 \\
\text { aras1 }\end{array}$ & 147 & 29,7 \\
\hline \multirow{7}{*}{$\begin{array}{c}\text { Haftalık } \\
\text { Yayın } \\
\text { İzleme } \\
\text { Süresi } \\
\text { (gün) }\end{array}$} & 1 gün & 51 & 10,3 & & $\begin{array}{l}27-32 \\
\text { aras1 }\end{array}$ & 42 & 8,5 \\
\hline & 2 gün & 96 & 19,4 & \multirow{6}{*}{$\begin{array}{c}\text { En Çok } \\
\text { İzlenen } \\
\text { Espor } \\
\text { Oyunu } \\
\text { Yayını }\end{array}$} & CS: GO & 126 & 25,5 \\
\hline & 3 gün & 93 & 18,8 & & DotA 2 & 54 & 10,9 \\
\hline & 4 gün & 63 & 12,7 & & LoL & 90 & 18,2 \\
\hline & 5 gün & 57 & 11,5 & & PUBG & 153 & 30,9 \\
\hline & 6 gün & 15 & 3,0 & & Valorant & 42 & 8,4 \\
\hline & Her gün & 120 & 24,2 & & WoW & 30 & 6,1 \\
\hline \multirow{4}{*}{$\begin{array}{c}\text { Günlük } \\
\text { Yayın } \\
\text { İzleme } \\
\text { Süresi } \\
\text { (saat) }\end{array}$} & $\begin{array}{c}1 \text { saatten } \\
\text { az }\end{array}$ & 108 & 21,8 & & & & \\
\hline & 1-3 saat & 273 & 55,2 & & & & \\
\hline & 3-5 saat & 93 & 18,8 & & & & \\
\hline & $\begin{array}{c}5 \text { saat } \\
\text { üzeri }\end{array}$ & 21 & 4,2 & & & & \\
\hline
\end{tabular}

Tablo 1'e göre araştırmaya katılan 495 kişiden 423'ünün erkek, 72'sinin ise kadın olduğu; katılımcıların 306'sının 18-22 yaş aralığında, 147'sinin 23-27 yaş aralığında ve 42'sinin 27-32 yaş aralığında olduğu görülmektedir. Katılımcıların 96'sının haftada 2 gün, 93'ünün haftada 3 gün, 63’ünün haftada 4 gün, 57'sinin haftada 5 gün, 51'inin haftada 1 gün, 15’inin haftada 6 gün, 120'sinin ise haftanın her günü espor yayınlarını izledikleri görülmektedir. Ayrıca kattlımcıların en çok izledikleri espor oyunu yayınlarına bakıldığında 153'ünün PUBG (PlayerUnknown's Battleground) 126'sının CS:GO (Counter Strike: Global Offensive), 90'ının LoL (League of Legends), 54'ünün Dota 2 (Defence of the Ancients 2), 42'sinin Valorant ve 30'unun WoW (World of Warcraft) yayınların izlediği; izleyicilerin günlük espor yayını izleme sürelerine bakıldığında ise 108 'inin 1 saatten az, 273'ünün 1 ile 3 saat arası, 93'ünün 3 ile 5 saat arası, 21'inin ise 5 saatten daha fazla espor yayını izlediği görülmektedir.

\subsection{Veri Toplama Araçları}

Espor İzleyici Talepleri Ölçeği (ESİTÖ): Qian, Zhang, Wang ve Hulland (2020) tarafindan espor izleyici taleplerini belirlemek amaciyla geliştirilen bu ölçeğin orijinal versiyonu sohbet odası (6 madde), yayın kalitesi (5 madde), yorum özellikleri (5 madde), oyuncu özellikleri (5 madde), etkinlik çekiciliği (4 madde), yayıncı özellikleri (3 madde), sanal ödüller (2 madde) ve zamanlama uygunluğu ( 2 madde) olmak üzere 8 alt boyuttan ve toplam 32 maddeden oluşmakta, 7’li likert tipinde derecelendirilmektedir. Sohbet odası alt boyutu; izleyicinin arkadaşlık duygusu geliştirme ve sohbet odasından etkilenme düzeyini, yayın kalitesi alt boyutu; izleyicinin ses kalitesinden, yayın çözünürlüğünden ve bağlantı akışından etkilenme düzeyini, yorum özellikleri alt boyutu; izleyicinin bilgilendirici ve aydınlatıcı yorumlardan etkilenme düzeyini, oyuncu özellikleri alt boyutu; izleyicinin profesyonel espor oyuncularının becerilerinden, oyun tarzlarından ve kişisel özelliklerinden etkilenme düzeyini, etkinlik çekiciliği alt boyutu; izleyicinin espor etkinliklerinin çekiciliğinden etkilenme düzeyini (örn; etkinlik kapsamının ve ödül havuzunun büyük olması olumlu bir etki olarak gösterilebilir), yayıncı özellikleri alt boyutu; izleyicinin eğlenceli ve etkileşimli olmasını beklediği yayıncı tarafindan etkilenme düzeyini, sanal ödüller alt boyutu; izleyicinin oyun içi sanal ödüllerden etkilenme düzeyini, program uygunluğu alt boyutu ise izleyicinin etkinlik programı planlamasından ve zamanlamasından etkilenme düzeyini (örn; etkinlik programının izleyicinin iş veya uyku saatine denk gelmemesi olumlu bir etki olarak gösterilebilir) belirtmektedir. 
Kilci, A. K., \& Yalçıner, S. (2020). Espor İzleyici Talepleri Ölçeği: Türkçe’ye uyarlama, geçerlik ve güvenirlik çalışması. Journal of Human Sciences, 17(4), 1106-1122. doi:10.14687/ihs.v17i4.6087

\section{3. Çeviri aşaması}

ESİTÖ'nün çeviri aşaması Bristlin, Lonner ve Thorndike (1973) tarafından önerilen çevirigeri çeviri tekniği (back to back translation) temel alınarak Türkçe’ye uyarlanmıştır. Bu doğrultuda ölçek İngilizce yeterliliğine sahip ve spor bilimleri alanından iki akademisyen ve bir dil uzmanı tarafından Türkçe'ye çevrilmiştir. Çeviriler araştırmacılar tarafindan incelenmiş ve en uygun ifadeler belirlenerek, yabancı dil uzmanı tarafından tekrar orijinal dili olan İngilizceye geri çevrilmiş ve ifadeler arasında anlam kayması olmadığı görülmüştür. Son olarak çalışma alanı espor olan iki araştırmacının görüşleri doğrultusunda düzenlemeler yapılarak ölçeğin çeviri işlemi tamamlanmıştır.

\subsection{Verilerin Toplanmas1}

Veri toplama işlemi, 2020 yılı Temmuz ve Ağustos ayları içerisinde www.onlineanketler.com sitesinde oluşturulmuş çevrimiçi anket formu aracillğıyla gerçekleştirilmiştir. Ölçeğin uygulanması için, çevrimiçi yayın platformu Twitch üzerinde yayın yapan yayıncılarla iletişime geçilmiş, ulaşılan yayıncılar çevrimiçi anket formu linkini izleyicileriyle paylaşmışlardır. Çevrimiçi anket formu'nda katılımcılar, ESİTÖ ile birlikte cinsiyet, yaş, izlemeyi en çok tercih ettikleri espor oyunu, haftada kaç gün espor yayını izledikleri ve günlük kaç saat espor yayını izledikleri hakkında bilgileri doldurmuş, ayrıca çalışmaya gönüllü olarak katıldıkları hakkında bilgilendirilmişlerdir.

\subsection{Verilerin Analizi}

Veri toplama issleminin ardından, toplanan verilerin analizleri SPSS 26 ve SPSS AMOS 25 istatistik programları ile gerçekleştirilmiştir. ESİTÖ, faktör yapısı açımlayıcı faktör analiziyle (AFA) incelenmiş ve faktör yükü değeri 0,32 'den küçük (Tabachnick ve Fidell, 2007) olan maddeler değerlendirilmeye alınmamıştır. AFA ile belirlenen faktörlerin ve oluşturulmuş olan modelin yapısınının değerlendirilmesi amacıyla doğrulayıcı faktör analizi (DFA) uygulanmıştır. Bazı uyarlama çalışmalarında AFA ve DFA'nın birlikte, bazılarında ise sadece DFA'nın kullanıldığı görülmektedir. Orcan (2018)'a göre uyarlama çalışmalarında yalnızca DFA'nın kullanılması; çeviri hatalarından ve kültürel farklılıklardan kaynaklanan sorunların ortaya çıkmasına yol açabilir. Ayrıca bir veri seti birden fazla DFA modeli ile uyum gösterebilir. Bu nedenle uyarlama çalışmalarında ilk olarak AFA yapılması uygun olacaktır. DFA uygulamalarında ilk olarak gözlenen değişkenler ile oluşturulan model arasındaki uyum indeksi değerlerine bakılması gerekmekte olup, modeller arasındaki farklılığın test edilebilmesi için ki kare $\left(\chi^{2}\right)$ değerine bakılmaktadır (Kafkas ve Özen, 2014). Fakat $\chi^{2}$ değeri örneklem genişliğine duyarlı olduğu için başka uyum indekslerinin de kullanımı önerilmektedir (Çokluk, Şekercioğlu ve Büyüköztürk, 2018). Model uyumunu belirlemek için birden fazla uyum indeksi vardır. Analizlerde hangi uyum indeksinin kullanılacağına dair kesin bir görüş olmamakla birlikte Meydan ve Şeşen (2015), Tabachnick ve Fidell (2007), Joreskog ve Sörbom (2001) modelin uyum iyiliğinin belirlenmesi amacıyla $\chi^{2}$ değerinin yanında; GFI, AGFI, CFI, NFI, RMR ve RMSEA, değerlerinin incelenmesi gerektiğini belirtmişlerdir. Bu çalışmada uyum iyiliği indekslerinden $\chi^{2}, \chi^{2} / s d$, GFI, AGFI, CFI, NFI, RMR ve RMSEA değerlerine bakılmıştır. Faktör yükleri değerlendirilirken Tabachnick ve Fidell (2007) faktör yükünün en az ,32 olması gerektiğini belirtirken; DeVellis (2012) en az ,40 ve Büyüköztürk (2018) en az ,45 olan faktör yükü değerlerini kabul etmektedir. Bu çalışmada faktör yükü değeri ,32 olarak kabul edilmiştir.

\subsection{Etik Onay}

$\mathrm{Bu}$ araştırmanın gerçekleştirilmesi için gerekli etik onay, Balıkesir Üniversitesi Sosyal ve Beşerî Bilimler Etik Kurulu'nun 02.07.2020 tarihli 2020/7 sayılı toplantı kararı ile alınmıştır. Ayrıca ölçek uyarlama çalışması için, orijinal versiyonun yayınlandığı makalenin sorumlu yazarı Yizhou Qian ile iletişime geçilmiş ve ölçeğin kullanılması için izin alınmıştır. 
Kilci, A. K., \& Yalçıner, S. (2020). Espor İzleyici Talepleri Ölçeği: Türkçe’ye uyarlama, geçerlik ve güvenirlik çalışması. Journal of Human Sciences, 17(4), 1106-1122. doi:10.14687/jhs.v17i4.6087

\section{Bulgular}

Araştırmanın bu bölümünde AFA ve DFA sonuçları verilmiştir.

\subsection{Yap1 Geçerliği}

\section{Açımlayıcı Faktör Analizi (AFA)}

Veri toplama süreci ardından elde edilen veri seti üzerinde AFA uygulamasından önce, toplanan verilerin faktör analizi için uygun olduğunun belirlenmesi gerekmektedir. Bu amaç doğrultusunda Kaiser-Meyer-Olkin (KMO) ve Bartlett testi uygulanmıştır. KMO ve Bartlett küresellik testleri verilerin, dağılımının faktör analizi için yeterliliğini ve örneklem büyüklügünün uygunluğunu belirlemek için kullanılmaktadır. Yapılan analizler sonucunda KMO değeri ,872 ve Bartlett küresellik testi değeri 9516,548 ( $p<0,05)$ olarak tespit edilmiştir. KMO ve Bartlett küresellik testi değerlerine göre elde edilen veri setinin faktör analizi yapılması için uygun olduğu belirlenmiştir.

Tablo 2. KMO ve Bartlett Küresellik Testi Sonuçları

\begin{tabular}{ccc}
\hline \multicolumn{2}{c}{ Kaiser-Meyer-Olkin Örneklem Ölçüm Değer Yeterliliği } &, 872 \\
\hline \multirow{3}{*}{ Bartlett's Küresellik Testi } & $\chi^{2}$ & 9516,548 \\
& sd & 496 \\
& Sig. &, 000 \\
\hline
\end{tabular}

KMO katsayısı araştırmalardaki örneklem büyüklügünün faktör analizi için yeterli olup olmadığının belirlenmesinde kullanılmaktadır. Sharma'ya (1996) göre bu değerin ,7-,79 arasında olması örneklem büyüklüğünün iyi, ,8-,89 arasında olması çok iyi ve ,9-1 arasında olması mükemmel olduğunu gösterirken; Kaiser (1974) örneklem büyüklüğünün kabul edilebilir olması için KMO katsayısının en az ,5 olması gerektiğini; ,5-,7 aralığının orta, ,7-,8 aralığının iyi, ,8-,9 aralığının çok iyi ve ,9'un üzerinde bir değere sahip örneklem grubunun ise faktör analizi için mükemmel durumda olduğunu belirtmiştir. Yapılan faktör analizi sonucunda KMO değerinin ,87 olması değişkenlerin faktör analizine uygunluğunun çok iyi düzeyde olduğunu göstermektedir (Tablo 2). Bartlett küresellik testi, elde edilen verilerin faktör analizi yapılması için uygun olup olmadığını belirleyen bir testtir. Bartlett küresellik testinde, elde edilen değerlerin istatistiksel olarak anlamlı olması durumunda $(\mathrm{p}<$ ,05) verilerin faktör analizi yapılması için uygun olduğu kabul edilmektedir (Munro, 2005; Şencan, 2005; Hair, Black, Babin, Anderson ve Tatham, 1998). Barlett testi sonucu incelendiğinde (Tablo 2) $(\mathrm{p}=, 00<, 05)$ ESİTÖ için elde edilen verilerin faktör analizi yapılmaya uygun olduğu görülmektedir. KMO değeri tüm soruların faktör analizi için uygunluğunu belirlerken, Örneklem Ölçüm Değer Yeterliliği (MSA) değeri ise ölçekteki maddelerin her birinin faktör analizine yapılması için uygun olup olmadığını ölçmekte ve bu değerleri Anti-Image Correlation (ters imaj korelasyon) matrisinde göstermektedir. Bu korelasyon matrisine göre ,5'den küçük değere sahip maddelerin analizden çıkarılması önerilmektedir (Yaşar, 2014). Ters imaj korelasyon matrisinde ,5'den düşük bir değer bulunmadığı için hiçbir madde ölçekten çıkarılmamıştır.

Tablo 3. İlk Varimax Döndürme Sonrası Oluşan Faktörlerin Özdeğerleri ve Açıladıkları Varyans Yüzdeleri

\begin{tabular}{ccccccc}
\hline & \multicolumn{3}{c}{ Başlangıç Özdeğerleri } & \multicolumn{2}{c}{ İlk Döndürme Sonrası Yük Kareleri } \\
Faktör & Toplamı & \\
\cline { 2 - 6 } & $\begin{array}{c}\text { Toplam } \\
\text { Özdeğer }\end{array}$ & Varyans \%'si & $\begin{array}{c}\text { Birikimli } \\
\text { \% }\end{array}$ & $\begin{array}{c}\text { Toplam } \\
\text { Özdeğer }\end{array}$ & $\begin{array}{c}\text { Varyans } \\
\text { \%'si }\end{array}$ & Birikimli \% \\
\hline 1 & 11,067 & 34,586 & 34,586 & 11,067 & 34,586 & 34,586 \\
2 & 2,592 & 8,1 & 42,686 & 2,592 & 8,1 & 42,686 \\
3 & 2,03 & 6,344 & 49,03 & 2,03 & 6,344 & 49,03 \\
4 & 1,703 & 5,323 & 54,354 & 1,703 & 5,323 & 54,354 \\
5 & 1,344 & 4,199 & 58,552 & 1,344 & 4,199 & 58,552 \\
6 & 1,208 & 3,776 & 62,328 & 1,208 & 3,776 & 62,328 \\
7 & 1,002 & 3,131 & 65,459 & 1,002 & 3,131 & 65,459 \\
\hline
\end{tabular}


Kilci, A. K., \& Yalçıner, S. (2020). Espor İzleyici Talepleri Ölçeği: Türkçe’ye uyarlama, geçerlik ve güvenirlik çalışması. Journal of Human Sciences, 17(4), 1106-1122. doi:10.14687/ihs.v17i4.6087

Verilerin analize uygunluğunun sınanmasının ardından veriler temel bileşenler analizine tabi tutulmuştur. Büyüköztürk'e (2018) göre temel bileşenler analizi bir değişken azaltma ve anlamlı kavramsal yapılara ulaşmayı amaçlayan, uygulamada en sık ve yaygın olarak kullanılan, okunması kolay bir istatistiksel yöntemdir. Veri seti üzerinden yapılan faktör analizinde faktör özdeğeri 1'den büyük olan faktörler anlamlı olarak belirlenmiştir. Başlangıçta faktör özdeğeri 1'den büyük olan yedi faktör bulunmuştur (Tablo 3). Bu doğrultuda yapılan faktör analizinde varimax yöntemiyle döndürülerek işleme sokulan maddelerin yük değerlerine bakılarak aynı anda birden fazla faktörde ,1'den düşük değer farkına sahip olan maddeler binişik madde olarak ele alınmış ve bu maddeler ölçekten çıkarılmıştır. Büyüköztürk (2018)'e göre aynı faktörlerde yer alan bir maddenin iki yük değeri arasında fark en az ,1 olmalıdır. Bu çerçevede varimax yöntemiyle yapılan döndürme sonrasında 21. madde aynı anda birden fazla faktörde ,1'den daha düşük yük değeri farkına sahip olduğu için bu madde binişik madde olarak kabul edilip ölçekten çıkarılmışır. 21. madde çıkartıldıktan sonra yapılan döndürme sonrasında 11. madde aynı anda birden fazla faktörde ,1'den düşük yük değeri farkına sahip olduğu için bu madde de binişik madde olarak kabul edilip ölçekten çıkarılmıştır. Aynı işlemler tekrarlanarak yapılan dik döndürme sonucunda aynı anda iki faktörde bulunan ve ,1'den düşük yük değeri farkına sahip olan 18. ve 29. maddeler de sırasıyla ölçekten çıkarılmıştır. Binişik olarak kabul edilen dört maddenin ölçekten çıkartılması sonucunda yeniden varimax döndürme işlemi uygulanmış 19. ve 20. maddelerin beraber (sadece 2 maddeden oluşan) bir alt boyut oluşturduklarn görülerek bu maddelerin de ölçekten çıkarılması uygun görülmüştür. Tekrar yapılan döndürme işleminin ardından altıncı faktör altında toplanan maddelerden 30. maddenin, faktör altındaki diğer maddelerle anlam bütünlüğü sağlamadığı düşünülerek bu madde de ölçekten çıkarılmıştır. 30. maddenin çıkartılmasının ardından yapılan yedinci ve son döndürme işlemi sonucunda toplam yedi madde ölçekten çıkarılmış ve kalan 25 madde ölçekte altı faktör altında toplanmıştır. Böylelikle ESİTÖ için; toplam varyansın \%67,278'ini açıklayan ve toplam özdeğeri 1'in üzerinde olan alt faktör belirlenmiştir (Tablo 4). DeVellis (2012), ölçek geliştirme ve uyarlama çalışmalarında toplam açıklanan varyansın en az \%40 olması gerektiğini belirtmiştir. Bu doğrultuda, ortaya çıkan açıklanan varyans değerinin iyi düzeyde olduğu görülmektedir.

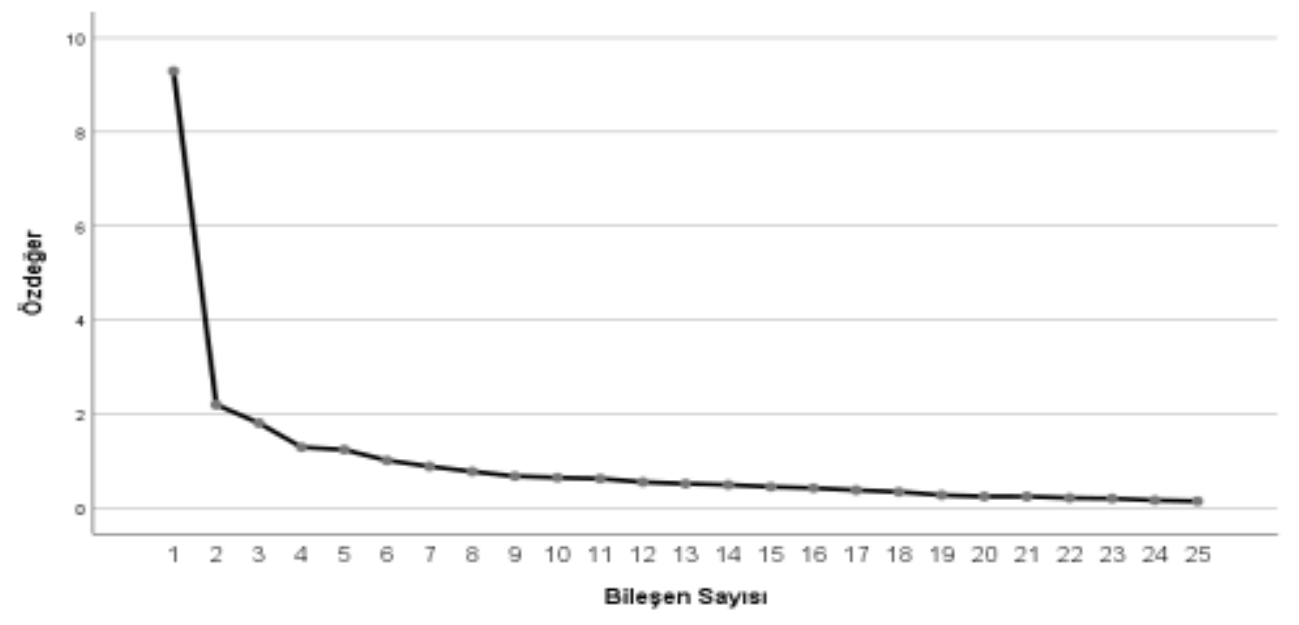

Şekil 1. ESİTÖ Yamaç Birikinti Grafiği

Ayrıca faktör sayısını belirlemek amacıyla Cattell (1966) tarafından geliştirilen Yamaç birikinti grafiği yöntemi dikkate alınmıştır. Gorsuch (1983), yamaç birikinti grafiğinininin, açımlayıcı faktör analizinde faktör sayısına karar verme noktasında baskın faktörleri belirlemeye yönelik bir grafik olduğunu belirtmiştir. Bu grafikte özdeğer ekseninden bileşen eksenine doğru bir eğim söz konusu olup, bu eğimde kırılmalar bulunur. Bu kırılmalar faktörlerin toplam varyansa katkıları doğrultusunda düşerek düz bir şekil alır. Eğimin azalmaya başladığı noktadan sonraki faktörlerin varyansa katkıları önemsenmeyecek büyüklükte olduğu için düz bir şekle dönüşür. Bu nedenle kırılma noktasına kadar 
Kilci, A. K., \& Yalçıner, S. (2020). Espor İzleyici Talepleri Ölçeği: Türkçe’ye uyarlama, geçerlik ve güvenirlik çalışması. Journal of Human Sciences, 17(4), 1106-1122. doi:10.14687/jhs.v17i4.6087

olan bileşen sayısı faktör sayısı olarak kabul edilir (Aktaran; Koçak, Çokluk ve Kayri, 2016). Şekil 1'de görüldüğü üzere eğimin altıncı noktasından sonra düzlük oluşmaya başlamaktadır. ESİTÖ yamaç birikinti grafiğinin altıncı noktasından sonra eğim düzlük oluşmaya başlamıştır (Şekil 1). Düzlügün oluşmaya başladığı altıncı nokta, kesme noktası olarak kabul edilmiş ve altı faktör belirlenmiştir. Altıncı noktadan sonra faktörlerin açıklanan varyansa etkisi azalmaya başladığından eğim yatay olarak seyretmektedir.

Faktör ve madde sayısının belirlenmesinin ardından oluşan faktörlerin isimlendirilmesi aşamasına geçilmiş; 1. faktör "Yaynn Kalitesı", 2. faktör "Sobbet Odası", 3. faktör "Yayma Özellikleri ve Zamanlama Uygunluğu”, 4. faktör "Etkinlik Türï", 5. faktör "Yorumcu Özellikleri” ve 6. faktör "Etkileşim ve Oyиnси Özellikler”" olarak isimlendirilmiştir. AFA sonrası ortaya faktörler, faktörlerin özdeğerleri ve açıladıkları varyanslar ile ölçekte bulunan 25 maddeye ait faktör yük değerleri Tablo 4'de sunulmuştur.

Tablo 4. Açımlayıcı Faktör Analizi Sonuçları

\begin{tabular}{|c|c|c|c|c|c|c|c|}
\hline \multirow{2}{*}{ Faktör Adı } & \multirow{2}{*}{ Maddeler } & \multicolumn{6}{|c|}{ Faktörler } \\
\hline & & 1 & 2 & 3 & 4 & 5 & 6 \\
\hline \multirow{4}{*}{ Yayın Kalitesi } & YK1 & 0,82 & & & & & \\
\hline & YK2 & 0,76 & & & & & \\
\hline & YK3 & 0,72 & & & & & \\
\hline & YK4 & 0,66 & & & & & \\
\hline \multirow{4}{*}{ Sohbet Odası } & SOE1 & & 0,79 & & & & \\
\hline & SOE2 & & 0,77 & & & & \\
\hline & SOE3 & & 0,67 & & & & \\
\hline & SOE4 & & 0,62 & & & & \\
\hline \multirow{5}{*}{$\begin{array}{l}\text { Yayıncı Özellikleri ve } \\
\text { Zamanlama Uygunluğu }\end{array}$} & YOZU1 & & & 0,72 & & & \\
\hline & YOZU2 & & & 0,66 & & & \\
\hline & YOZU3 & & & 0,62 & & & \\
\hline & YOZU4 & & & 0,58 & & & \\
\hline & YOZU5 & & & 0,50 & & & \\
\hline \multirow{4}{*}{ Etkinlik Türü } & ET1 & & & & 0,84 & & \\
\hline & ET2 & & & & 0,78 & & \\
\hline & ET3 & & & & 0,68 & & \\
\hline & ET4 & & & & 0,64 & & \\
\hline \multirow{3}{*}{ Yorumcu Özellikleri } & OÖ1 & & & & & 0,79 & \\
\hline & OÖ2 & & & & & 0,78 & \\
\hline & OÖ3 & & & & & 0,70 & \\
\hline \multirow{5}{*}{$\begin{array}{l}\text { Etkileşim ve Oyuncu } \\
\text { Özellikleri }\end{array}$} & EOO1 & & & & & & 0,71 \\
\hline & EOO2 & & & & & & 0,66 \\
\hline & EOO3 & & & & & & 0,51 \\
\hline & EOO4 & & & & & & 0,45 \\
\hline & EOO5 & & & & & & 0,38 \\
\hline ÖZDEĞER & & 3,47 & 3,05 & 2,8 & 2,78 & 2,74 & 1,96 \\
\hline AÇIKLANAN VARYANS & 67,278 & 13,881 & 12,221 & 11,231 & 11,128 & 10,965 & 7,851 \\
\hline
\end{tabular}

\section{Doğrulayıc1 Faktör Analizi (DFA)}

Doğrulayıcı faktör analizi, AFA ile belirlenen faktörlerin birbirlerinden bağımsız olup olmadığını, bu faktörler arasındaki ilişkiyi, faktörlerin oluşturulan modeli açıklama düzeyini sınamak için ölçek geliştirme ve geçerlik çalışmalarında sıkça kullanılan, daha önceden belirlenmiş bir kurgusal yapının istatistiksel olarak doğrulandığı analiz yöntemidir (Özdamar, 2010; Bayram, 2016). DFA genellikle, başka kültürlerde ve örneklemlerde geliştirilmiş ölçme araçlarının uyarlanmasında kullanılan bir geçerlik belirleme yöntemidir (Seçer, 2017). 
Kilci, A. K., \& Yalçıner, S. (2020). Espor İzleyici Talepleri Ölçeği: Türkçe’ye uyarlama, geçerlik ve güvenirlik çalışması. Journal of Human Sciences, 17(4), 1106-1122. doi:10.14687/jhs.v17i4.6087

Belirlenen model üzerinde yapılan DFA'nın ardından, uyum indeksleri aracıllğıyla model yapısının veriler ile uyum gösterip göstermediği belirlenmektedir. Uyum indeksleri, oluşturulan modelin kabul edilip edilmemesine karar verme amacıyla kullanılmaktadır (Bayram; 2016; Ayyıldız ve Cengiz, 2006). Ki-kare uyum testi, GFI, CFI ve RMSEA değerleri, oluşturulan modelin uyum indeksini test ederken en çok incelenen değerlerdir (Schumacker \& Lomax, 2004).

Tablo 5. Oluşturulan ESITTÖ Modelinin Uyum İndeksi Değerleri

\begin{tabular}{c|c|c|c|c|}
\hline $\begin{array}{c}\text { Uyum } \\
\text { Indeksi }\end{array}$ & $\begin{array}{c}\text { Model } \\
\text { Sonucu }\end{array}$ & $\begin{array}{c}\text { Mükemmel } \\
\text { Uyum }\end{array}$ & $\begin{array}{c}\text { Kabul Edilebilir } \\
\text { Uyum }\end{array}$ & Model Uyumu \\
\hline$\chi^{2}$ & 187,274 & - & - & - \\
$\mathrm{p}$ &, 00 & $>, 05$ &, $01 \leq \mathrm{p} \leq, 05$ & Uyumlu değil \\
$\chi^{2} / \mathrm{df}$ & 2,622 & $0 \leq \chi^{2} / \mathrm{df} \leq 2$ & $\chi^{2} / \mathrm{df} \leq 3$ & Kabul edilebilir \\
GFI &, 896 & $0,90 \leq \mathrm{GFI} \leq 1,00$ & $\geq, 85$ & Kabul edilebilir \\
AGFI &, 892 & $0,90 \leq \mathrm{AGFI} \leq 1,00$ & $\geq, 85$ & Kabul edilebilir \\
CFI &, 918 & $0,97 \leq \mathrm{CFI} \leq 1,00$ & $\geq, 90$ & Kabul edilebilir \\
NFI &, 902 & $0,95 \leq \mathrm{GFI} \leq 1,00$ & $\geq, 90$ & Kabul edilebilir \\
RMR &, 064 & $\leq, 05$ &, $06 \leq \mathrm{p} \leq, 08$ & Kabul edilebilir \\
RMSEA &, 071 & $0 \leq \mathrm{RMSEA} \leq 0,05$ & $\leq, 08$ & Kabul edilebilir \\
\hline
\end{tabular}

Kaynak: Hair ve ark., (1998); Blunch, (2008); Byrne, (2010); Tabachnick ve Fidell, (2007); Schumacker ve Lomax, (2004); Sümer (2000)

DFA sonucunda, 25 madde ve 6 alt boyuttan oluşan ESİTÖ’nün uyum indekslerinin kabul edilebilir düzeyde olduğu görülmüştür. Başar’a (2016) göre maddelerin standardize edilmiş regresyon katsayılarının ,40'ın üzerinde olması, maddelerin ait oldukları faktörlere iyi düzeyde uyum sağladığınının göstergesidir. DFA sonucunda standardize edilmiş regresyon katsayısı ,40'ın altında katsayı değerine sahip madde olmadığı belirlenmiştir. Oluşturulan modelde 25 madde ve 6 faktör olduğu tespit edilmiştir. Modelin uyum indekslerine ait değerlerin; ki-kare $\chi^{2}=187,274 ; \chi^{2} / \mathrm{df}=2,622$; GFI=,896; $\mathrm{AGFI}=, 892 ; \mathrm{CFI}=, 918 ; \mathrm{NFI}=, 902 ; \mathrm{RMR}=, 064$ ve RMSEA=,071 olduğu görülmektedir (Tablo 5). Bu değerlerin model uyumu için kabul edilebilir düzeyde olduğu ancak model uyum indekslerinden $\mathrm{p}$ değerinin model ile uyumlu olmadığı belirlenmiştir. Model uyum indekslerinde incelenmesi önerilen p değerinin anlamlı olmaması $(\mathrm{p}>, 05)$ gerekmektedir. Fakat, Meydan ve Şeşen'e (2015) göre bir modelin $\chi^{2} /$ df oranının kabul edilebilir olması modelin genel olarak uyumlu olduğunu işaret etmektedir. Bundan dolayı oluşturulan modelin uyum değerlerinin kabul edilebilir düzeyde olduğu söylenebilir. 
Kilci, A. K., \& Yalçıner, S. (2020). Espor İzleyici Talepleri Ölçeği: Türkçe’ye uyarlama, geçerlik ve güvenirlik çalışması. Journal of Human Sciences, 17(4), 1106-1122. doi:10.14687/jhs.v17i4.6087

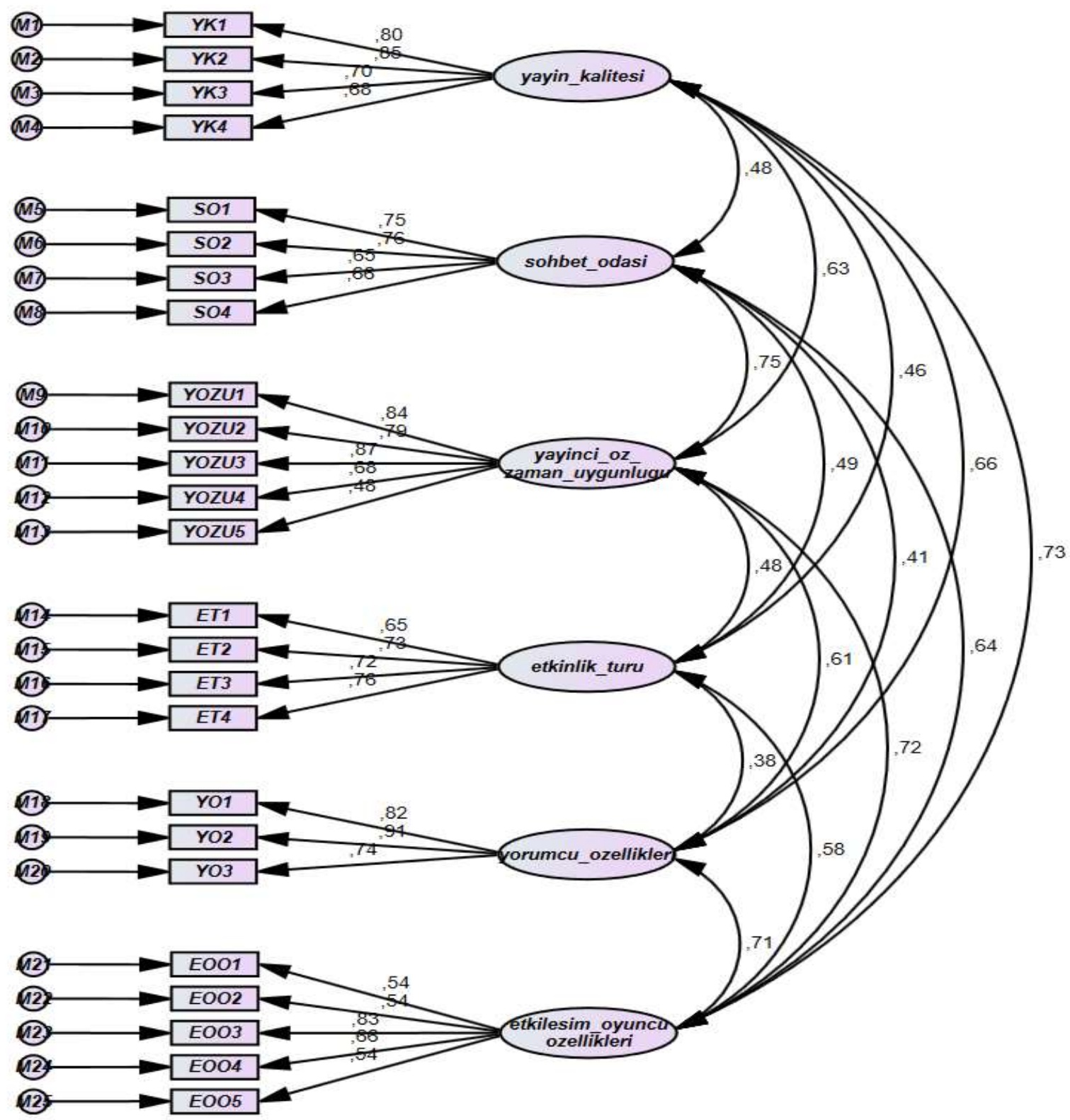

Şekil 2. Espor İzleyici Talepleri Ölçeği Yol Analizi

Şekil 2'de gözlenen değişkenlerin gizil değişkenleri açıklama düzeyine ilişkin standardize edilmiş yol katsayı değerleri verilmiştir. Şekil 2'ye göre ESİTÖ maddelerinin standardize edilmiş yol katsayı değerlerinin ,54 ile ,91 arasında değiştiği görülmektedir. Bu değerlerin ,1'den büyük olmas1 istenirken; ,11-,49 arasında olması "orta etki”, ,5’in üzerinde olması ise "büyük etki” gösterdiğini ifade etmektedir (Kline, 2015). Diğer bir deyişle standardize edilmiş yol katsayı değerleri, gözlenen değişkenlerin örtük değisskenlere olan etkisini belirtmektedir. ESİTÖ yol analizi sonucu incelendiğinde tüm maddelerin ait oldukları gizil değişkenler (alt boyutlar) üzerinde "büyük etki" düzeyine sahip olduğu söylenebilir.

\section{Geçerlik ve Güvenirlik Analizleri}

Açımlayıcı ve doğrulayıcı faktör analizleri tamamlanıp oluşturan modelin doğrulanmasının ardından, modelde yer alan maddelerin ve faktörlerin güvenirliklerinin belirlenmesi aşamasına geçilmiştir. Güvenirlik, katılımcıların kullanılan ölçme araçlarına verdikleri cevaplar arasındaki tutarlılıktır. Diğer bir deyişle güvenirlik analizleri, kullanılan anketlerin veya ölçeklerin güvenilirliğini belirlemek için kullanılan analizlerdir (Büyüköztürk, 2018; Kalayc1, 2018). Likert tipindeki ölçeklerin 
Kilci, A. K., \& Yalçıner, S. (2020). Espor İzleyici Talepleri Ölçeği: Türkçe’ye uyarlama, geçerlik ve güvenirlik çalışması. Journal of Human Sciences, 17(4), 1106-1122. doi:10.14687/jhs.v17i4.6087

güvenirlik düzeyleri hesaplanırken iç tutarlılık analizinin kullanılması önerilmektedir. İç tutarlılık güvenirlik katsayısı, ölçekteki her bir maddenin ölçeğin yapısının tamamıyla uygun olup olmadığının bir göstergesi olup, ölçekteki her madde ile bağlı oldukları faktörler (gizli değişkenler) arasındaki korelasyonu belirler. Bu korelasyon katsayısının yüksek değere sahip olması ölçeğin iç tutarlıllğının da yüksek düzeyde olduğu anlamına gelmektedir (DeVellis, 2012). ESİTÖ’nün iç tutarlılık güvenirlik düzeyini belirlemek için, ölçekte bulunan maddelerin türdeş bir yapıyı açıklayacak bir bütün oluşturup oluşturmadıklarını belirten ve hesaplaması toplam puanlar aracıllğıyla gerçekleştirilen likert tipi ölçeklerin güvenirliğinin hesaplanmasında sıkça kullanılan bir iç tutarlllık ölçütü "Cronbach’s Alpha" ölçekte yer alan soruların eşdeğer bir şekilde ikiye bölünerek her iki yarıda bulunan maddelerin toplamından oluşan iki değişken arasındaki güvenirliği ifade eden "Split-Half' (ikiye bölme) ve birleşik güvenirlik (CR) yöntemleri kullanılmıştır. Birleşme geçerliğinin tespitinde ise açıklanan ortalama varyans (AVE) değerine bakılmıştır. Cronbach's Alpha katsayısının “,6-,79” arasında olması geliştirilen ölçeğin oldukça güvenilir, ,8-1 arasında olması ise geliştirilen ölçeğin yüksek güvenirliğe sahip olduğunu gösterirken, CR değerinin ,7'nin; AVE değerinin ,5'in üzerinde, ikiye bölme analizinde korelasyon katsayısının ,2-,9 arasında olması ve Spearman Brown katsayısının ise ,7'nin üzerinde bir değere sahip olması ölçeğin güvenilir olarak kabul görülmesi için yeterlidir (Alpar, 2010; Hinkin, 1995; Hair, Ringle ve Sarstedt, 2013; Fornell ve Larcker, 1981). Ayrıca birleşme geçerliliğinin sağlanması için CR değerlerinin AVE değerlerinden büyük olması beklenmektedir (Eskiler ve Altunışı, 2017). Ancak, diğer güvenirlik değerlerinin yeterli olduğu düşünüldüğü durumlarda, AVE değerinin ,5'den küçük bir değere sahip olması araştırmacılar tarafindan "kabul edilebilir" bir durum olarak görülmektedir (Fornell \& Larcker, 1981; Berthon, Eving ve Hah, 2005).

Tablo 6. Cronbach's Alpha, CR, AVE Sonuçları

\begin{tabular}{ccccc}
\hline Faktör Adı & $\begin{array}{c}\text { Madde } \\
\text { Sayısı }\end{array}$ & $\begin{array}{c}\text { Cronbach's } \\
\text { Alpha }\end{array}$ & CR & AVE \\
Yayın Kalitesi & 4 &, 840 &, 799 &, 497 \\
Sohbet Odası & 4 &, 796 &, 799 &, 478 \\
Yayıncı Özellikleri ve Zamanlama & 5 &, 838 &, 828 &, 556 \\
Uygunluğu & 4 &, 807 &, 799 &, 513 \\
Etkinlik Türü & 3 &, 863 &, 749 &, 693 \\
Yorumcu Özellikleri & 5 &, 755 &, 829 &, 400 \\
Etkileşim ve Oyuncu Özellikleri & 25 &, 924 &, 961 &, 512 \\
ÖLÇEK & & &
\end{tabular}

Tablo 6'ya göre; AFA ve DFA sonucunda ölçekte yer alan "Yayın Kalitesi" faktörünün Cronbach's Alpha değeri ,840, CR değeri ,799 ve AVE değeri ,497; "Sohbet Odası" faktörünün Cronbach's Alpha değeri ,796, CR değeri ,799 ve AVE değeri ,478; "Yayınc1 Özellikleri ve Zamanlama Uygunluğu” faktörünün Cronbach's Alpha değeri ,838, CR değeri ,828 ve AVE değeri ,556; “Etkinlik Türü” faktörünün Cronbach's Alpha değeri ,807, CR değeri ,799 ve AVE değeri ,513; "Yorumcu Özellikleri” faktörünün Cronbach's Alpha değeri ,863, CR değeri ,749 ve AVE değeri ,693; “Etkileşim ve Oyuncu Özellikleri” faktörünün Cronbach's Alpha değeri ,755, CR değeri ,829 ve AVE değeri ,400 bulunurken, ölçeğin bütününün Cronbach's Alpha değeri ,924, CR değeri ,961 ve AVE değeri ,512 olarak tespit edilmiştir. Cronbach Alpha katsayılarının ,755-,924; CR katsayılarının ,799-,961 arasında olması nedeniyle ölçeğin iç tutarlılık güvenirliğinin sağlandığı, tüm faktörlerin ve ölçeğin bütününün CR değerlerinin AVE değerlerinden yüksek olması ve "Yayın Kalitesi”, "Sohbet Odası" ve "Etkileşim ve Oyuncu Özellikleri" faktörlerinin AVE değerlerinin ,400-,497 arasında oldukları göz önüne alındığında bu faktörlerin birleşme geçerliğinin "kabul edilebilir" düzeyde olduğu, "Yayıncı Özellikleri ve Zamanlama Uygunluğu”, "Etkinlik Türü”, "Yorumcu Özellikleri” ve ölçeğin bütününün ise birleşme geçerliğinin sağlandığı ifade edilebilir. 
Kilci, A. K., \& Yalçıner, S. (2020). Espor İzleyici Talepleri Ölçeği: Türkçe’ye uyarlama, geçerlik ve güvenirlik çalışması. Journal of Human Sciences, 17(4), 1106-1122. doi:10.14687/ihs.v17i4.6087

Tablo 7. İkiye Bölme (Split-Half) Güvenilirlik Analizi

\begin{tabular}{|c|c|c|c|c|}
\hline \multirow[b]{2}{*}{ Faktörler } & \multirow{2}{*}{ 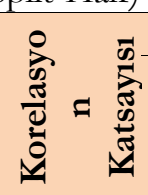 } & \multicolumn{2}{|c|}{ Spearman-Brown Katsayıs1 } & \multirow{2}{*}{ 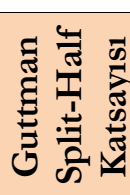 } \\
\hline & & $\begin{array}{c}\text { Eşit } \\
\text { Uzunluk }\end{array}$ & $\begin{array}{c}\text { Eşit } \\
\text { Olmayan } \\
\text { Uzunluk }\end{array}$ & \\
\hline Yayın Kalitesi & ,706 & 828 & 828 & 827 \\
\hline Sohbet Odası & 607 & 756 &, 756 &, 755 \\
\hline $\begin{array}{c}\text { Yayıncı Özellikleri ve Zamanlama } \\
\text { Uygunluğu }\end{array}$ &, 541 & ,702 & 709 & 666 \\
\hline Etkinlik Türü & ,678 & 808 & 808 & 807 \\
\hline Yorumcu Özellikleri & 687 & 814 & 829 & ,706 \\
\hline Etkileşim ve Oyuncu Özellikleri & 618 &, 764 &, 770 & ,734 \\
\hline ÖLÇEK &, 723 & 839 & 839 & 838 \\
\hline
\end{tabular}

Tablo 7'ye göre, "Yayın Kalitesi” faktörü; espor izleyicilerinin yayınlardaki ses kalitesinden, görüntü kalitesinden ve yayının akıcılığından ne ölçüde etkilendiğini açıklamaktadır. Bu faktörde yer alan dört madde üzerinde gerçekleştirilen ikiye bölme analizi sonucuna göre korelasyon katsayı değeri ,706; Spearman-Brown katsay1s1 ,828 ve ,828 Gutmann ikiye bölme test değeri ise ,827 olarak belirlenmiştir. "Sohbet Odası" faktörü; izleyicilerin espor yayınlarındaki sohbet kanalının sahip olduğu mizah oluşturma, izleyiciler arasında etkileşim yaratma ve arkadaşlık duygusunu geliştirme gibi özellikler aracılı̆̆ılla sohbet odasından ne ölçüde etkilendiğini açıklamaktadır. Bu faktörde yer alan dört madde üzerinde gerçekleştirilen ikiye bölme analizi sonucunda; korelasyon değeri katsayısı ,607; Spearman-Brown katsayıs1 ,756 ve ,756; Gutmann ikiye bölme test değeri ise ,755 olarak belirlenmiştir. "Yayınc1 Özellikleri ve Zamanlama Uygunluğu” faktörü; espor izleyicilerinin hangi etkinlik türlerini izlemeyi tercih ettiklerini açıklamaktadır. Bu faktörde yer alan beş madde üzerinde gerçekleştirilen ikiye bölme analizi sonucuna göre korelasyon katsayı değeri ,541; Spearman-Brown katsayıs1,702 ve ,709; Gutmann ikiye bölme test değeri ise ,666 olarak olarak belirlenmiştir. "Etkinlik Türü" faktörü; espor izleyicilerinin hangi etkinlik türlerini izlemeyi tercih ettiklerini açıklamaktadır. Bu faktörde yer alan dört madde üzerinde gerçekleştirilen ikiye bölme analizi sonucuna göre korelasyon katsayı değeri ,678; Spearman-Brown katsayıs1,808 ve ,808; Gutmann ikiye bölme test değeri ise ,807 olarak belirlenmiştir. "Yorumcu Özellikleri" faktörü; izleyicilerin bilgilendirici ve açıklayıcı yorumlar yapan anlatıcılardan ne ölçüde etkinlendiğini açılarken bu faktörde yer alan üç madde üzerinde gerçekleştirilen ikiye bölme analizi sonucuna göre korelasyon katsayı değeri ,687; Spearman-Brown katsayısı ,814 ve ,829; Gutmann ikiye bölme test değeri ise ,706 olarak olarak belirlenmiştir. "Etkileşim ve Oyuncu Özellikleri” faktörü; izleyicilerin izledikleri esporcuların becerilerinden, oyun stillerinden ve kişisel özelliklerinden ne ölçüde etkilendiğini açıklarken bu faktörde yer alan beş madde üzerinde gerçekleştirilen ikiye bölme analizi sonucunda korelasyon katsayı değeri ,618; Spearman-Brown katsayıs1,764 ve ,770; Gutmann ikiye bölme test değeri ise, 734 olarak olarak belirlenmiştir. Ölçekte yer alan yirmi beş maddenin tümü üzerinde yapılan ikiye bölme analizi sonucuna göre korelasyon değeri ,723; Spearman-Brown katsayıs1, 839 ve ,839; Gutmann ikiye bölme test değeri ise ,838 olarak olarak belirlenmiştir. Elde edilen değerler, ölçekte yer alan faktörlerin ve ölçeğin tamamının güvenilir olduğunu belirtmektedir.

\section{Tartışma ve Sonuç}

Bu çalışma Qian, Zhang, Wang ve Hulland (2020) tarafindan, espor izleyici taleplerini belirlemek amacıyla geliştirilen SESD'in özgün dilden Türkçe diline uyarlanması ve Türkçe formunun (ESİTÖ) geçerlik ve güvenirliğinin belirlenmesi amaciyla gerçekleştirilmiştir. Ölçeğin orijinal formunun Türkçe diline çevirisi yapılırken Bristlin ve arkadaşları (1973)'nın önerdiği, çeviri-geri çeviri tekniği (back to back translation) esas alınmıştır. Ölçeğin Türkçe formunun oluşturulmasının ardından geçerlik ve güvenirlik çalışması Twitch üzerinden espor yayınlarını izleyen 495 espor izleyicisi ile gerçekleştirilmiştir. Ölçeğin geçerliğini belirlemek ve Türk kültüründeki yapısını 
Kilci, A. K., \& Yalçıner, S. (2020). Espor İzleyici Talepleri Ölçeği: Türkçe’ye uyarlama, geçerlik ve güvenirlik çalışması. Journal of Human Sciences, 17(4), 1106-1122. doi:10.14687/ihs.v17i4.6087

değerlendirebilmek amacıyla AFA yapılmış ve yapı geçerliğine bakılmıştır. Verilerin faktör analizi için uygunluğunu belirlemek amacıyla KMO ve Bartlett küresellik testleri uygulanmış ve verilerin faktör analizi yapılmasına uygun olduğu belirlenmiştir $(\mathrm{KMO}=, 872$; Bartlett Küresellik Değeri < ,05). AFA sonuçları incelendiğinde, ESITÖ̈ Türkçe formunun ilk olarak yedi faktörlü bir yapıya sahip olduğu görülmüş fakat binişik olan maddeler (21.-11.-18. ve 29. madde) sırasıyla ölçekten çıkarılmıştır. Son binişik madde çıkarıldıktan sonra yapılan döndürme işleminin ardından 19. ve 20. maddelerin de sadece iki maddeden oluşan bir faktör oluşturdukları görülmüş ve ölçekten çıkarılmıştır. Tekrar yapılan döndürme işlemi sonucunda 30. maddenin de bulunduğu faktördeki diğer maddelerin anlam bütünlüğü sağlamadığı düşünülmüş ve ölçekten çıkarılmıştır. Maddelerin çıkarılmasının ardından yapılan döndürme işlemi sonrası özdeğeri 1'in üzerinde ve toplam varyansın \%67,278'sini açılayan 6 faktör ve 25 maddeden oluşan bir yapı elde edilmiştir. Belirlenen faktörler; ölçeğin orijinal formu, literatür ve maddelerin özellikleri dikkate alınarak "Yayın Kalitesi", "Sohbet Odası", "Yayınc1 Özellikleri ve Zamanlama Uygunluğu", "Etkinlik Türü", "Yorumcu Özellikleri” ve "Etkileşim ve Oyuncu Özellikleri" olarak isimlendirilmiştir. "Yayın Kalitesi” faktörü içerisinde bulunan maddelerin faktör yüklerinin ,66 ile ,82 arasında; "Sohbet Odası" faktörü içerisinde bulunan maddelerin faktör yüklerinin ,62 ile ,79 arasında; "Yayınc1 Özellikleri ve Zamanlama Uygunluğu” faktörü içerisinde bulunan maddelerin faktör yüklerinin ,50 ile ,72 arasında; "Etkinlik Türü" faktörü içerisinde bulunan maddelerin faktör yüklerinin ,64 ile ,84 arasında; "Yorumcu Özellikleri” faktörü içerisinde bulunan maddelerin faktör yüklerinin ,70 ile ,79 arasında ve "Etkileşim ve Oyuncu Özellikleri” faktörü içerisinde bulunan maddelerin faktör yüklerinin ise ,38 ile ,71 arasında değiştiği görülmektedir. Ölçekte yer alan maddelerin belirtilen faktör yükleri ile yeterli düzeyde olduğu söylenebilir. Ayrıca belirlenen faktörlerin toplam varyansa etkisi yeterli düzeydedir $(\% 67,278)$.

AFA'nın ardından, ESITTÖ üzerinde altı faktör ve yirmi beş maddeden oluşan doğrulayıcı faktör analizi modeli oluşturulmuştur. Oluşturulan modelin uyum indekslerinden; ki-kare uyum değeri $\left(\chi^{2} / \mathrm{DF}=2,622\right)$, uyum iyiliği indeksi değeri (GFI= ,896), (AGFI= ,892); karşılaştırmalı uyum indeksi değeri $(\mathrm{CFI}=, 918)$, normlaştırilmış uyum indeksi $(\mathrm{NFI}=, 902)$, hata kareler ortalamasının karekökü $(\mathrm{RMR}=, 064)$ ve yaklaşık hataların ortalama karekökü değerlerinin (RMSEA=,071) kabul edilebilir düzeyde olması modelin uyumlu olduğunu göstermektedir.

ESİTÖ modelinin uyumlu olduğunun belirlenmesinin ardından güvenirlik analizleri gerçekleştirilmiştir. Güvenirlik analizi kapsamında iç tutarlık katsayısı; ölçeğin genelinde ,924; "yayın kalitesi" faktöründe ,840; "sohbet odası" faktöründe ,796; “yayınc1 özellikleri ve zamanlama uygunluğu” faktöründe ,838; “etkinlik türü” faktöründe ,807; “yorumcu özellikleri” faktöründe ,863 ve "etkileşim ve oyuncu özellikleri”" faktöründe ise ,755 olarak belirlenmiştir. Ayrıca ölçeğin güvenirliğini test etmek için yarıya bölme (split-half) analizi uygulanmış ve ölçeğin genelinin korelasyon katsayısının ,723; Spearman-Brown katsayısının ,839; eşit olmayan uzunluk katsayısının ,839 olduğu, ayrıca ölçekteki faktörlerin korelasyon değerlerinin ,541 ile ,706 arasında ve SpearmanBrown eşit uzunluk değerlerinin ,702 ile ,828 arasında ve eşit olmayan uzunluk değerlerinin ,709 ile ,829 arasında değiştiği tespit edilmiştir. Bu değerler göz önünde bulundurulduğunda ölçeğin bütününün ve ölçekte yer alan altı faktörün de ideal güvenirlik değerlerine sahip olduğu görülmektedir.

Çalışma sonucunda ESİTÖ’nün Türk kültüründeki espor izleyicilerinin yayın/yayıncıdan taleplerinin belirlenmesinde geçerli ve güvenilir bir ölçme aracı olarak kullanılabileceği söylenebilir. ESİTÖ'nün, Türkiye'de yeni bir araştırma alanı olan espor alanına, espor alanında çalışmalar gerçekleştiren araştırmacılara ve bu alana ilgi duyan bireylere katkıda bulunacağı düşünülmektedir.

\section{Kaynakça}

Alpar, R. (2010). Spor, sağlık ve eğitim bilimlerinden örneklerle uygulamalı istatistik ve geçerlikgüvenirlik. Detay yayınclik.

Ayyıldız, H., \& Cengiz, A. G. E. (2006). Pazarlama Modellerinin Testinde Kullanılabilecek Yapısal Eşitlik Modeli (Yem) Üzerine Kavramsal Bir İnceleme. Süleyman Demirel Üniversitesi İktisadi Ve İdari Bilimler Fakültesi Dergisi, 11(2), 63-84. 
Kilci, A. K., \& Yalçıner, S. (2020). Espor İzleyici Talepleri Ölçeği: Türkçe’ye uyarlama, geçerlik ve güvenirlik çalışması. Journal of Human Sciences, 17(4), 1106-1122. doi:10.14687/ihs.v17i4.6087

Başar E.E. (2016). Hane Halklarının Sürdürülebilir Tüketim Davranışlarının Ölçülmesine Yönelik Bir Ölçek Geliştirme Çalışması, Atatürk Üniversitesi, Sosyal Bilimler Enstitüsü, İşletme Anabilim Dalı. Doktora Tezi, Erzurum.

Bayram, N. (2016). Yapısal eşitlik modellemesine giriş amos uygulamaları. [Introduction to structural equation modeling] Bursa: Ezgi Kitabevi.

Berthon, P., Ewing, M., \& Hah, L. L. (2005). Captivating company: dimensions of attractiveness in employer branding. International Journal of Advertising, 24(2), 151-172.

Blunch, N. J. 2008. Introduction to Structural Equation Modelling Using SPSS and AMOS. London: SAGE Publications.

Bristlin, R. W., Lonner, W. J. ve Thorndike, R. M. (1973). Cross-cultural research methods. New York: John Wiley\&Sons.

Brown, K. A., Billings, A. C., Murphy, B., \& Puesan, L. (2018). Intersections of fandom in the age of interactive media: eSports fandom as a predictor of traditional sport fandom. Communication \& Sport, 6(4), 418-435.

Büyüköztürk, Ş. (2018). Sosyal bilimler için veri analizi el kitabı. İstatistik, araştırma deseni. SPSS uygulamaları ve yorum. (24. Bask1). Ankara: Pegem Yayıncilık.

Byrne, B. (2010) Structural Equation Modeling With AMOS: Basic Concepts, Applications and Programming (Multivariate Applications), (2nd edition). London: Routledge.

Cattell, R. B. (1966). The scree test for the number of factors. Multivariate behavioral research, 1(2), 245-276.

Charts, E. (2018). Worlds 2018 -200 million viewers at once. Esports Charts. Erişim tarihi: 1 Ekim 2020. Erişim adresi: https://escharts.com/blog/worlds-2018-final

Cunningham, G. B., Fairley, S., Ferkins, L., Kerwin, S., Lock, D., Shaw, S., \& Wicker, P. (2018). eSport: Construct specifications and implications for sport management. Sport Management Review, 21, 1-6.

Çokluk, Ö., Şekercioğlu, G., \& Büyüköztürk, Ş. (2012). Sosyal bilimler için çok değişkenli istatistik: SPSS ve LISREL uygulamaları (Vol. 2). Ankara: Pegem Akademi.

DeVellis, R.F. (2012). Ölçek Geliştirme: Kuram ve Uygulamalar (Ed. Tarık Totan), Ankara: Nobel Yayincilik.

Eskiler, E ve Altunışık, R. (2017). Rol model alma davranışının pozitif sözlü iletişim ve satın alma niyeti üzerine etkisinde marka bağlılığının aracllık rolü, Uluslararası Yönetim İktisat ve İşletme Dergisi, ICMEB17 Özel Say1s1, 687-696.

Fornell, C., \& Larcker, D. F. (1981). Evaluating structural equation models with unobservable variables and measurement error. Journal of marketing research, 18(1), 39-50.

Funk, D. C., Pizzo, A. D., \& Baker, B. J. (2018). eSport management: Embracing eSport education and research opportunities. Sport Management Review, 21, 7-13.

Gorsuch, R. L. (1983). Factor Analysis. Philadelphia: Saunders.

Hair, J. F., Black, W. C., Babin, B. J., Anderson, R. E., \& Tatham, R. L. (1998). Multivariate data analysis (Vol. 5, No. 3, pp. 207-219). Upper Saddle River, NJ: Prentice hall.

Hair, J. F., Ringle, C. M., \& Sarstedt, M. (2013). Partial least squares structural equation modeling: Rigorous applications, better results and higher acceptance. Long range planning, 46(1-2), $1-12$.

Hallmann, K., \& Giel, T. (2018). eSports-Competitive sports or recreational activity? Sport Management Review, 21, 14-20.

Hamari, J., \& Sjöblom, M. (2017). What is eSports and why do people watch it?. Internet research.

Heere, B. (2018). Embracing the sportification of society: Defining e-sports through a polymorphic view on sport. Sport Management Review, 21, 21-24.

Hinkin, T. R. (1995). A review of scale development practices in the study of organizations. Journal of management, 21(5), 967-988.

Joreskog, K. \& Sörbom, D. (2001). LISREL 8: User's Reference Guide, Scientific Software International, Lincolnwood. 
Kilci, A. K., \& Yalçıner, S. (2020). Espor İzleyici Talepleri Ölçeği: Türkçe’ye uyarlama, geçerlik ve güvenirlik çalışması. Journal of Human Sciences, 17(4), 1106-1122. doi:10.14687/jhs.v17i4.6087

Kafkas, M. E. ve Özen, G. (2014). Obezite Farkındalık Ölçeği (OFÖ)’ nin Türkçeye uyarlanması: bir geçerlik ve güvenirlik çalışması. İnönü Üniversitesi, Beden Eğitimi ve Spor Bilimleri Dergisi, 1(2), 1-15.

Kaiser, H. F. (1974). An index of factorial simplicity. Psychometrika, 39(1), 31-36.

Kalaycı, Ş. (2018). Faktör Analizi, Kalaycı Ş. (Ed.) içinde SPSS Uygulamalı Çok Değişkenli İstatistik Teknikleri, 8. Bask1. Ankara: Dinamik Akademi.

Kline, R. B. (2015). Principles and practice of structural equation modeling. Guilford publications.

Koçak, D., Çokluk, Ö., ve Kayri, M. (2016). Faktör sayısının belirlenmesinde MAP testi, paralel analiz, K1 ve yamaç birikinti grafiği yöntemlerinin karşılaştırılması. Yüzüncü Yul Üniversitesi Eg̈itim Fakültesi Dergisi, 13(1), 330-359.

Lee, D., \& Schoenstedt, L. J. (2011). Comparison of eSports and traditional sports consumption motives. ICHPER-SD Journal of Research, 6, 39-44.

Lee, J. Y., An, J. W., \& Lee, S. W. (2014). Factors affecting eSports audience satisfaction:

Meydan, C., \& Şeşen, H. (2015). Yapısal Eşitlik Modeli AMOS Uygulamaları. 2. Baskı. Detay Yayınc1lik: Ankara.

Munro, B. H. (2005). Statistical methods for health care research (Vol. 1). Lippincott williams \& wilkins.

Newzoo. 2019. Newzoo: Global Esports Economy Will Top \$1 Billion for the First Time in 2019. Erişim Tarihi: 5 Ekim 2020. Erişim adresi: https://newzoo.com/insights/articles/newzooglobal-esports-economy-will-top-1-billion-for-the-first-time-in-2019/

Newzoo. 2020. Newzoo: The Global Esports Audience Will Be Just Shy of 500 Million This Year. Erişim tarihi: 2 Ekim 2020. Erişim adresi: https://newzoo.com/insights/articles/newzooesports-sponsorship-alone-will-generate-revenues-of-more-than-600-million-this-year/

Orcan, F. (2018). Exploratory and Confirmatory Factor Analysis: Which One to Use First?. Journal of Measurement and Evaluation in Education and Psychology, 9 (4), 414-421. DOI: 10.21031/epod.394323.

Özdamar, K. (2010). Paket programlar ile istatistiksel veri analizi II (çok değişkenli analizler) Statistical data analysis with package programs II (multivariate analysis), Kaan Kitabevi, 7. Baskı, Eskişehir.

Pizzo A.D., Baker B.J., Na S., Lee M.A., Kim D., Funk D.C. Esport vs. sport: a comparison of spectator motives. Sport Mark Q 2018, 27(2): 108-123.

Qian, T. Y., Zhang, J. J., Wang, J. J., \& Hulland, J. (2020). Beyond the game: Dimensions of esports online spectator demand. Communication \& Sport, 2167479519839436.

Schumacker, R. E., \& Lomax, R. G. (2004). A beginner's guide to structural equation modeling. Psychology press.

Seçer, İ. (2017). SPSS ve LISREL ile pratik veri analizi (3. Baskı). Ankara: Anı Yayıncilık.

Sekaran, U. (2003). Research Methods for Business: A Skill-Building Approach. 4th Edition, John Wiley \& Sons, New York.

Seo, Y. (2013). Electronic sports: A new marketing landscape of the experience economy. Journal of Marketing Management, 29(13-14), 1542-1560.

Sharma, S., ve Sharma, S. (1996). Applied multivariate techniques.

Statista. 2020. eSports audience size worldwide from 2018 to 2023. Erişim Tarihi: 1 Ekim 2020. Erişim adresi: https://www.statista.com/statistics/1109956/global-esports-audience/

Sümer, N. (2000). Yapisal Eşitlik Modelleri: Temel Kavramlar ve Örnek Uygulamalar. Türk Psikoloji Yazılar1.

Şencan, H. (2005). Sosyal ve davranışsal ölçümlerde geçerlilik ve güvenilirlik (1.Basım). Ankara. Seçkin Yayıncılık.

Tabachnick, B. G. ve Fidell, L. S. (2007). Using multivariate statistics (Vol. 5, pp. 481-498). Boston, MA: Pearson.

Taylor, N. T. (2016). Now you're playing with audience power: The work of watching games. Critical Studies in Media Communication, 33(4), 293-307. 
Kilci, A. K., \& Yalçıner, S. (2020). Espor İzleyici Talepleri Ölçeği: Türkçe’ye uyarlama, geçerlik ve güvenirlik çalışması. Journal of Human Sciences, 17(4), 1106-1122. doi:10.14687/ihs.v17i4.6087

The case of League of Legends. Journal of Korea Game Society, 14, 35-46.

Türk Dil Kurumu. 2020. Erişim Tarihi: 6 Ekim 2020. Erişim adresi: https://sozluk.gov.tr/

Yaşar, M. (2014). Eğitimde ölçme ve değerlendirme dersine yönelik tutum ölçeğinin geliştirilmesi. Eg̈itim Bilimleri Arastırmalan Dergisi, 4(1), 259-279.

\section{Extended English Summary}

\section{Introduction}

With the globalization of broadcast networks (internet, television, etc.), broadcasts have reached the potential of accessing hundreds of thousands or even millions of viewers at the same time. On the other hand, one of the events that is broadcast and watched globally and which has recently increased its popularity is "Esports". Esports; are competitive events organized by different leagues and tournaments, around competitive video games, and between professional or amateur teams, often supported by various business organizations (Hamari \& Sjöblom, 2017). Esports can be seen as the intersection point of video games and professional sports (Brown et al., 2018).

The rapidly growing esports industry has an organized structure with the establishment of national and international esports organizations (Seo, 2013) (e.g. International Esports Federation, Turkish Esports Federation). Esports and traditional sports (football, basketball, etc.); It has similar features such as having professional players, teams, and coaches, being organized in leagues and tournaments, and having player transfer fees (Pizzo et al., 2018). Esports events are generally made available to viewers via streaming platforms (Twitch, Youtube, etc.) by esports tournament organizations (eg ESL) and individual professional/amateur players (Taylor, 2016). Along with these, it is observed that recently television channels have started broadcasting esports competitions. This is thought to be since esports events have an ever-growing spectator (Statista, 2020) and advertising/sponsorship revenues increase each year (Newzoo, 2020). Esports' economy and spectators continue to grow steadily (Newzoo, 2019; Newzoo, 2020). As a result, it is thought that scientific research on esports should be increased and the various features of the spectator should be examined. One of these is the requests of the esports viewers from the broadcast/broadcaster.

According to the Dictionary of the Turkish Language Association (2020), the demand is expressed as "What is required from someone else to fulfill, purpose, request". Ekenci and İmamoğlu (2002) stated that the "demand" phenomenon for sports services and programs "Who has sufficient purchasing power and free time; individuals or groups who want to benefit from sports services and programs in a certain period and line with specific goals. They stated that it can be handled as. Also, stating that the mass demanding these services may consist of those directly participating in sports or the spectator; They also underlined that the customer who consumes the sports programs produced by the sports business is a very important factor in the sustainability of the business. However, it was stated that the quality of the service provided can be explained with the concept of "compliance with expectations" and the evaluation of the quality of the service can be followed by customer satisfaction (Ekenci \& İmamoğlu, 2002). In line with this information, it is an undeniable fact that viewers who follow esports broadcasts can participate in these sports programs as viewers without having the power to purchase and that they are consumers of these resources. Accordingly, spectator demands; can be explained as the qualities that the spectator wants and does not want in broadcasts/broadcasters. Publishers to be aware of these demands arising from expectations; Therefore, it is thought that taking initiatives to meet these demands is important in terms of reaching more viewers and satisfying the existing spectator. If we give a few examples; A broadcaster who broadcasts individually and fails to read and respond to comments during the broadcast will also be more likely to lose viewers who expect to respond to their comments. Similarly; The possibility of losing viewers who expect high image fluency and quality 
Kilci, A. K., \& Yalçıner, S. (2020). Espor İzleyici Talepleri Ölçeği: Türkçe’ye uyarlama, geçerlik ve güvenirlik çalışması. Journal of Human Sciences, 17(4), 1106-1122. doi:10.14687/jhs.v17i4.6087

will also increase for the broadcaster who performs a broadcast that does not have high image fluency and quality.

It is thought that the broadcasters, by determining the spectator expectations with many similar dimensions and shaping their broadcasts in line with these expectations, will help them reach larger spectators and satisfy the larger part of their spectator.

\section{Method}

The universe of this study has consisted of viewers following "CSGO", "PUBG", "DotA 2", "LoL", "Valorant" and "WoW" broadcasts through the Twitch platform in Turkey. The original form of the scale was adapted to Turkish with the back-translation technique recommended by Lonner and Thorndike (1973). For the implementation of the scale, broadcasters who broadcasting on the online streaming platform Twitch were contacted and the publishers reached shared the link to the online questionnaire form with their spectators. Participants who filled online survey form; shared information about gender, age, the most preferred esports game to watch, how many days a week they watched esports broadcasts, and how many hours they watched esports broadcasts per day, and they were informed about their voluntary participation in the study. After the data collection process, the analysis of the obtained data was carried out with SPSS 25 and SPSS AMOS 23. After the data collection process, the analysis of the collected data was carried out with SPSS 26 and SPSS AMOS 25 statistical programs. The factor structure of the Turkish version of the SESD was examined with exploratory factor analysis (EFA) and items with a factor load value less than 0.32 (Tabachnick \& Fidell, 2007) were not included in the evaluation. Confirmatory factor analysis (CFA) was applied to evaluate the factors determined by EFA and the structure of the model created.

\section{Findings, Discussion, and Results}

It has been observed that the 6 -factor structure has a good fit $(\chi 2=187.274 ; \chi 2 / \mathrm{df}=2.622$; $\mathrm{GFI}=.896 ; \mathrm{AGFI}=.892 ; \mathrm{CFI}=.918 ; \mathrm{NFI}=.902 ; \mathrm{RMR}=.064 ; \mathrm{RMSEA}=.071)$ applied to evaluate the factors and the structure of the scale determined after EFA. It was determined that the internal consistency coefficients of the scale based on sub-dimensions ranged between .755 and .863, and the overall internal consistency coefficient was $\alpha=.924$. A structure consisting of 6 factors and 25 items with an eigenvalue above 1 and explaining $67,278 \%$ of the total variance was obtained. Determined factors were named as "Broadcast Quality", "Chat Room", "Broadcaster Features and Schedule Convenience", "Event Type", "Commentator Features" and "Interaction and Player Features", considering the original version of the scale, literature, and the features of the items. As a result of the study, it can be said that the Turkish version of the SESD (ESITO) can be used as a valid and reliable measurement tool in determining the demands of the esports audience in Turkish culture from the broadcast/broadcaster. It is thought that ESITO will contribute to the field of esports, which is a new research area in Turkey, researchers working in the field of esports, and individuals who are interested in this field. 